\title{
Character Education of Balinese Local Wisdom-Based Through the Integration Social Studies Subject
}

\author{
$1^{\text {st }}$ I Wayan Kertih* \\ Faculty of Law and Social Sciences \\ Ganesha University of Education Singaraja, \\ Bali, Indonesia \\ iwayankertih@gmail.com
}

\begin{abstract}
This research aimed at explaining the practices of cultivation of national character values at the school environment and teaching and learning of social studies as well as the consequent implications. The research employed educational ethnography design, involving all academic civitas (principal, teachers, and employees), school committees, and community leaders. The data were analyzed in a qualitative approach. The research results demonstrated that social and cultural contexts of societies, both directly and indirectly, were involved in giving color to the educational atmosphere at Junior High School 1 Singaraja. It was the societies' socio-cultural contexts accommodated in the school's vision, namely: "Excellent, Civilized, and GloballyOriented" made the philosophical, sociocultural, and psychological bases in the administration of educational practices in general and in teaching and learning of social studies. The educational practices inseparable
\end{abstract}

\section{INTRODUCTION}

Development of the nation's character to realize the independence of a civilized and dignified nation is a very important thing to do in Indonesia [1]. The idea of the importance of building the nation's character substantively has long been echoed by the nation's founders. Ir. Sukarno, the first president of the Republic of Indonesia was one of many figures in Indonesia who initiated the importance of building the nation's character in the concept of "Nation and character-building". Unfortunately, a noble idea to realize the life of a civilized and dignified nation and the state as conceived by the from the social contexts which are able to embody a school environment as a strong medium for characterization for all the academic civitas and for the students' empowerment to develop knowledge and insight, values and attitude, and social skills participatory in teaching and learning of the local, national, and global socio-cultural lives. According to these research findings, some recommendations were developed, namely: the necessary to develop the creation of such educational atmosphere learning inseparable from local wisdom and social traditions, the practicing of democratic leadership; social studies curriculum on the basis of social reconstruction approach; the necessary to develop content, model or approach, resources, media teaching and learning social studies contextual and authentic assessment.

Keywords-Character Education, Social Studies, Local Wisdom

founders of the nation is still far from the expectations. It shows that various efforts made in the effort to build the nation's character have been lacking, even it is ineffective.

The weaknesses in education practice in Indonesia have occurred when the character education is perceived in an understanding which is not integrated into each subject and school curriculum. Meanwhile, in learning there is a process emphasizing the provision of knowledge (transfer of knowledge) compared with activities allowing the internalization of values [2]. This educational practice also appears in Social Studies learning showing that the 
implementation barely tends to involve lowlevel cognitive activities that are lack mental activities that have the dimension of morality. Further said, Social Studies learning is only able to make students smart to memorize facts, concepts, and events, but it is lack and meaningless [3], [4], [5].

Based on the fact, phenomenon, and assumptions as described above, and learning from weaknesses in the implementation of character education programs in Indonesia, so this study is important to be conducted. It is supported by several reasons: (1) this study is in line with efforts to reform and innovate education in schools in general, and Social Studies education in particular that emphasizes the priority of national character education; (2) a comprehensive study on the implementation and development of national character education in junior high school education units, especially in Bali, has not been done much by previous researchers; (3) a study of Social Sciences education in national character education discourse is important to do because as an integral part of the school curriculum, Social Sciences subjects have the responsibility in developing the nation's character education program. How is national character education implemented and developed in Social Sciences learning in SMP Negeri 1 Singaraja?. This is the main problem examined in this study.

\section{METHOD}

This research generally uses a qualitative research design. Following the problem and its purpose, this study used an ethnographic study design of education combined with case studies [6]. This research focuses on describing and providing a detailed explanation of phenomena in Social Sciences learning that happened at SMPN 1 Singaraja. In this study, researchers were directly involved to conduct participatory observation, in-depth interviews, discussions, and study existing documents. To be able to play such a role, the research procedure is carried out using the principles of qualitative research work, in which the data collection process and data analysis are carried out simultaneously and cycle.The data were collected through observation, interview, a document study, and discussion methods use of Learning Outcomes
Tests. The process of data analysis in this study was carried out simultaneously and cycle by the process of data collection which is often referred to as the interactive cycle data analysis process. In Analyzing data, the researcher applied various activities, they were data reduction, data display, data interpretation, data verification, and conclusion drawing [7]. The process and steps of data analysis above are a series of activities that synergize and take place repeatedly, until the final research result is obtained, namely: ethnographic that is grounded, holistic and full of meaning, in the context of answering the focus of the research problem.

\section{RESULTS AND DISCUSSION}

This subdivision presented the results of research and discussion relating to the efforts of schools and teachers to integrate the values of national character in the Social Sciences learning process, as follows. Based on observations related to the efforts of teachers in developing national character education materials, it showed that teachers were trying to instill character values in students by providing examples of cases that occur in their environment. In several meetings, the teacher seemed to deliberately provide opportunities for students to help solve controversial issues about Ethnic and Religion issues and conflicts between local, national, and global interests that were particularly found to be quite commonin Bali and generally in Indonesia. On the other hand, it seems that the teachers could also understand that the Social Sciences education process at schools carried a message of nationalism values and interests in the framework of building society, united, and Indonesian country which is strong, untied and message of values and interests globally along with the level of development of global society in this millennium era.

The important elements of community life that surround the school, seem often used as examples to clarify the concepts and facts contained in textbooks. For example, in discussing material on the socialization process, the textbook only explains about the types of socialization processes. Likewise, the material on social interaction, in the textbook only described the forms of social interaction and the process of social interaction. For the development of this 
material, the teacher gave an example of the process of interaction that occurs in the Anyar Market, which is the place for interaction of various individuals with various backgrounds and interests. Furthermore, the teacher assigned students to make direct observations about the interaction process that occurs in the Anyar Market, and present it at the next meeting. In discussing other material, the teacher also used examples of the existence of social institutions that are different groups of supporters from the point of view of religion and culture can coexist; Buleleng community warrior figures who can be emulated, local wisdom of the Buleleng community in particular, and Bali, in general, are still in accordance with today's life, culture as an example for the development of students' character values.

From the results of observations on Social Scienceslearning, it appeared that in general, the teacher has applied a teaching approach that activates students more by applying various learning methods. Some methods that appear to have been designed in the syllabus and lesson plans developed include cooperative learning, discussion, assignments, questions and answers, observations, and other methods, including inquiry, field visits. The learning process is also inseparable from the socio-cultural context that surrounds the school through experiences that provide an opportunity to gather information and shape into abstract ideas about how people interact. Learning is the process of finding information, processing it, then learning to solve problems and practice to make decisions, develop and analyze values. Learning activities are also not always carried out in the classroom, but also carried out outside the classroom. According to the teacher, it was done to provide a different atmosphere from the usual atmosphere in the classroom. According to students, learning whichwas done at any time outside the classroom could make him more excited to follow the lessons given by the teacher rather then it was always done in class.

Judging from the assessment aspects developed by the teacher, it appeared that the assessment of student learning outcomes was carried out only using the technique of giving multiple-choice objective test forms to students both on formative, sub-summative tests, as well as on summative tests and during school exams. For the assessment of the process, the teacher said that using observations of activities, attitudes, behaviors, and character values integrated into Social Sciences learning. Related to the evaluation of character values integrated into Social Sciences learning, teachers admitted that they were still experiencing uncertainty and difficulty in evaluating these aspects. Therefore, for the assessment of this aspect, they usually coordinate with the teacher of Counseling Guidance and homeroom teacher.

\section{Discussion}

From the whole process implemented in Social Sciences learning, it appeared that Social Sciences learning conducted by teachers was lacking and even could be said it did not reflect yet its realization as a nation's character education program. Although the teacher has been able to integrate character values in the learning program (syllabus and lesson plans), however, it was not so visible in practice, even tends to be overlooked, both in the development of the material, learning and in the assessment process which was implemented.

In terms of material development, the weakness of the teacher was when the teacher explained about social interactions, for example, what should be taught should not only be concepts and facts but must also explain the values behind the historical facts [8] [9]. Other things that also seem less optimal were the efforts of teachers to empower important elements of community life, and the use of symbols as media and learning resources in Social Sciences learning. Whereas various important elements of community life are available in the school and the environment around the school which can be used as a medium to habituate character values.

In connection with the learning undertaken, it appears that it has not demonstrated the principles of learning that strive for students to recognize and accept cultural values and national character as their own and be responsible for the decisions taken through the stages of recognizing choices, assessing choices, determining positions, and then make a value in accordance with self-confidence. The learning 
developed also has not shown any effort so that students learn through the process of thinking, behaving, and doing. These three processes are intended to develop the ability of students to carry out social activities and encourage students to see themselves as social creatures In connection with the learning undertaken, it appears that it has not demonstrated the principles of learning that strive for students to recognize and accept cultural values and national character as their own and be responsible for the decisions taken through the stages of recognizing choices, assessing choices, determining positions, and then make a value in accordance with self-confidence. The learning developed also has not shown any effort so that students learn through the process of thinking, behaving, and doing. These three processes are intended to develop the ability of students to carry out social activities and encourage students to see themselves as social creatures [10] [11].

It is important to be implemented because character education is not a teaching process that is merely information transfer. Character education is also not a mere process of instilling values. Similarly, character education is not only training students to have technical and vocational skills alone. More than all that, character education is the process of facilitating, guiding, encouraging, encouraging, accompanying, directing, strengthening, and giving examples or examples to students how all their potential can be actualized optimally into various forms of capabilities that will shape the character or personality of participants students. The potentials that can be empowered are also holistic and multidimensional. These potentials can be seen from the integrity of aspects: knowledge, values and attitudes, skills, confidence, commitment, and competence [12].

The learning process in the context of character education in schools should be carried out in its entirety, in the sense of involving the entire range of potential possessed by children. Every child has the potential of both intellectual, emotional, morality, and sociality which must be fully developed. The learning process also cannot be separated from the socio-cultural context in which children grow and develop. Social Sciences education as a vehicle for the nation's character education must aim to develop the life skills of citizenship on the subject of students as a whole, meaningful, and authentic both concerning personal, social, intellectual, academic, academic or vocational skills. To achieve these goals, students are required not only to rely on themselves from what is happening in the classroom, but must be willing and able to explore the variety of learning resources needed. Some research has revealed that community life and the environment around schools can be used as a source of learning or as a field of study in Social Scienceslearning. The use of the community environment as a source of learning can develop effective values that lead to the socio-economic and cultural aspects of the surrounding community. The results of these studies suggest that the use of the environment and community life settings as learning resources directs the process and student learning outcomes to aspects related to community life, and various aspects of interests related to it [13] [14] [15]. The most visible thing in Social Sciences learning does not reflect the realization of the implementation of character education programs is the assessment conducted, which is limited only to rely on assessment in the form of tests. Social Sciences education as a vehicle for national character education will also be effective if the implementation of the assessment process and student learning outcomes are more authentic. For this assessment of the learning process and learning outcomes of students must be whole, comprehensive, authentic, meaningful, honest, transparent, objective, integrated, educating, empowering, and not sentencing. The use of assessment strategies with interviews, observations, written test descriptions, performance tests, self-assessments, and portfolios are the main conditions for achieving the objectives of Social Sciences learning as a vehicle for the nation's character education effectively.

Based on the explanation above, it is clear that the philosophical foundation which is suitable to be used as a foundation for teachers in developing Social Sciences education programs in schools does not merely rely on the mere thought of educational essentialism, but also relies on more progressive thinking. In this 
more progressive view, teachers believe that Social Sciences education is a process that grows and develops by reconstructing the experience of social life continuously as a learning process. Social Sciences education, therefore, is not an effort to prepare children for adult life, but rather a dynamic social life process. This can only be done in a democratic social life that allows everyone to participate and be actively involved in the lives of the people who are undergoing a process of transformation. Social Sciences education must prepare children to be active in the learning process that reflects the social structure of a democratic society to guide the subject of students to change their behavior. On that basis, the Social Sciences program must provide an educational curriculum that is based on the needs of students and the community and utilizes the application of intelligence to human problems in the community. Learning that is relevant to curriculum programs as above is learning that actively involves the role of students in the participatory learning process, cooperative work, learning by doing, and the inquiry process [16], [17].

At schools, especially Social Sciences teachers are required not only to develop a sociopedagogical mission but also to develop the socio-academic and socio-cultural mission of the community [12], [18]. By socio-pedagogical mission, Social Sciences Education is an educational and teaching program of concepts and values that has a nationalist perspective in the material content of facts, events, and basic concepts of Social Sciences taught curricular in class. By socio-academic mission, Social Sciences Education is strived to become a vehicle for students to develop their social knowledge academically and scientifically through simple scientific research activities or simple reflective inquiry activities. Unfortunately, it is recognized that the implementation of socio-academic missions tend to still be marginalized even though it is not ignored at all. It means, besides not being systematically programmed, academic development activities in learning social curricular both curricular and in curricular and extracurricular activities is still very limited.

Finally, through socio-cultural mission, Social Sciences education not only empowers students to be more balanced in their appreciation of national and global cultural values and more so on local culture, but also provides more opportunities for students to participate socially in developing community and practicing local social and cultural values (especially Balinese culture based on Hinduism) directly, both in activities creating the overall socio-cultural climate in the school environment, extra curricular activities based on local and national cultures, and even in activities- community activities in a harmonious relationship between the school and the community. The realization of this socio-cultural mission is primarily intended to educate, teach, and train students to always respect and act in accordance with local cultural characteristics (act locally), but still, facilitate students to have the ability to think globally, and respect and have committed to national cultural values (respect to the nationalism or commit nationally). The vision and mission of Social Sciences education like this are considered to be closer to the Social Sciences education program in schools with the needs and development of the community, both at the local level (Buleleng people in particular and Bali in general), national and global.

\section{CONCLUSIONS}

The teacher understands that Social Sciences education is essentially carrying out the mission as a national character education program, but in reality, it is not easy for the teacher to realize the mission. Curricular, as a consequence of the national social education curriculum imple mentation policy, teachers actually cannot escape from their interpretation of the curriculum which emphasizes the subject matter approach. In connection with the integration of the nation's character education program, teachers have integrated it into the syllabus and lesson plans it develops. However, it was not formulated in the learning objectives that were carried out. The teacher views that the integration of national character education is only an accompanying impact of Social Sciences learning, not a competency that students must have. The implication, Social Sciences education is carried out no more than learning material facts and basic concepts from several Social Sciences and humanities such as History, 
Geography, Economics, and Sociology, using conventional learning and assessment methods.

As an integral part of school education, Social Sciences education is also a national character. Therefore, the practice of social education needs to be viewed and developed from the perspective of developing local culture, without ignoring the ideals of commitment to national life, and developing the ability to think globally (think globally, act locally, respect and commit to the nationalism). Social Sciences education in schools as a vehicle for the nation's character education needs to be viewed and developed in the perspective of developing local culture, without ignoring the ideals of commitment to national life, and the development of global thinking skills. In the language of education, vision can be formulated is to produce people who can think globally, act locally, and respect to the nationalism.

Social studies education should ideally be able to give birth to young people who have faith and piety (have a good conviction, devotion, and karma discourse), master knowledge, intelligent, and skilled and have an autonomous personality with the capacity to make rational and responsible decisions, have a commitment to ethnic identity that upholds the noble values of its local culture, has the soul and ability to advance national culture in the context of shaping the nation's character.

\section{ACKNOWLEDGMENTS}

The researcher says thank you to the Ministry of Research Technology and Higher Education. The researcher also says thank you to LPPM UNDIKSHA which facilitates the research processes. The researcher also says thank you to the principal, teachers, and students of SMPN 1 Singaraja who cooperates for this research.

\section{REFERENCES}

[1] Pemerintah Republik Indonesia. (2010). Pembangunan Karakter Bangsa 2010-2025; Desain Induk. Jakarta: Kemendiknas.

[2] S. Pasandaran. (2010). Integrasi Pendidikan Karakter ke dalam Kurikulum Sekolah, in Seminar Nasional dan Forum Pimpinan FIS, FISE, FPIPS, JPIPS se Indonesia, Manado.
[3] Budimansyah and Sapriya. (2012). Refleksi Implementasi Project Citizen dalam Pembelajaran Pendidikan Kewarganegaraan di Indonesia, Bandung: Budimansyah dan Sapriya. (2012). Refleksi Implementasi Project Citizen dalam Pembelajaran PendWidya Aksara Press.

[4] I. W. Kertih and Sukadi. (2007). Konsep Ajeg Bali (Hindu) Berbasis Idiologi Tri Hita Karana Dimaknai di Lingkungan Sekolah (Studi Etnografi Pendidikan pada SMA Negeri I Ubud Bali sebagai Model SMA Berwawasan Hindu). Jurnal Penelitian dan Pengembangan Sains \& Humaniora, 1(2), pp. 143-155.

[5] S. A. Muchtar. (2000). Epistimologi Pendidikan Ilmu Pengetahuan Sosial, Bandung: Gelar Pustaka Mandiri.

[6] J. W. Creswell and C. N. Poth. (2016). Qualitative inquiry and research design: Choosing among five approaches. United States of America: Sage Publications.

[7] M. B. Miles and A. M. Huberman. (1992). Analisis Data Kualitatif: Buku Sumber tentang Metode-metode Baru. Jakarta: UI Press.

[8] R. Kevin and B. Kahlen. (1999). Building Character in School. San Francisco : John Wiley and Sons, Inc.

[9] U. S. Winataputra. (2010). Pengembangan Karakter dan Nilai-nilai Demokrasi, in Seminar Nasional Revitalisasi Pancasila dalam Pembangunan Karakter Bangsa, Semarang.

[10] Pemerintah Republik Indonesia. (2010). Kebijakan Nasional Pembangunan Karakter Bangsa. Jakarta: Kemko. Kesejahteraan rakyat.

[11] S. H. Hasan. (2010). Inovasi Pembelajaran IPS dalam Membangun Karakter Peserta Didik. Bandung: FPIPS-LPI.

[12] U. S. Winataputra. (2010). Peran Pendidikan Ilmu Perngetahuan Sosial (PIPS) dalam Konteks Pembangunan Karakter Bangsa; Kebijakan, Konsep, dan Kerangka Programatik. Jakarta: Universitas Terbuka.

[13] J. Jarolimek. (1986). Social Studies in Elementary Education. New York-London: Macmillan Publishing Company and Collier Macmillan Publishers.

[14] G. M. Schuncke. (1988). Elementary Social 
Studies; Knowing, Doing, Caring. USA: MacMillan Pub.Co.

[15] P. H. Martorella. (1996). Teaching Social Studies in Middle and Secondary Scholls. Englewood Cliffs, NJ: Prentice-Hall.

[16] P. F. Oliva. (1992). Developing the Curriculum. 3rd Edition. New York: Harper Collins Publishers, Inc.

[17] W. F. O'Neil. (2001). Ideologi-ideologi Pendidikan. Yogyakarta: Pustaka Pelajar.

[18] Y. Pai. (1990). Cultural Foundations of Education. New York: Macmillan Publishing Company.

[19] P. F. Carspecken. (1996). Critical Ethnography in Educational Research: A Theoretical andPractical Guide. New York and London: Routledge.

[20] F. Fukuyama. (1985). Confucianism and Democracy. Journal of Democracy, 6(3), pp. 20-30.

[21] T. Lickona. (1996). Eleven Principles of Effective Character Education. Journal of Moral Education, 5(1).

[22] T. Lickona. (1992). Educating for Character. New York: Bantam Books.

[23] M. N. Somantri. (2001). Menggagas Pembaharuan Pendidikan IPS. Bandung: PT. Remaja Rosdakarya. 